\title{
Infections and endoscopy: A reminder
}

\author{
PG RosSOS, MD, G KANDEL, MD
}

\begin{abstract}
Although infectious complications of endoscopy are unusual, the morbidity and mortality associated with this problem are so severe that a review of the issue is warranted. The risk of bacteremia after endoscopy is greatest after sclerotherapy and esophageal dilation; however, the benefit of antibiotic prophylaxis has not been well studied in any situation. Recommendations for endocarditis prophylaxis vary widely in the literature. Most authorities advise antibiotic prophylaxis if there is either significant heart disease (particularly if prosthetic valves are present), and/or if the risk of bacteremia is high after the particular endoscopic procedure to be carried out. All patients should be managed as if they have the potential to spread hepatitis B and human immunodeficiency virus. Accordingly, universal precautions should be taken in the endoscopy unit, with the use of gowns and eye protection during endoscopy of all patients. The most important aspect of disinfecting endoscopic equipment is manual scrubbing and cleaning of all instruments. Two per cent activated glutaraldehyde inactivates both human immunodeficiency virus and hepatitis B, and is therefore recommended as the disinfectant of first choice. Can J Gastroenterol 1990; $4(9): 663-666$
\end{abstract}

Key Words: Disinfection, Endocarditis, Endoscopy, Infections, Prophylaxis

\section{Infections et endoscopie: Rappel}

RESUME: Bien que les complications infectieuses de l'endoscopie soient rares, la morbidité et la mortalité associées au problème sont suffisamment sévères pour justifier une analyse de la question. Le risque de bactériémie après endoscopie est le plus élevé après la sclérothérapie et la dilatation oesophagienne; néanmoins, l'avantage d'une antibiothérapie préventive n'a été convenablement étudié dans aucune situation. Les recommandations de mesures prévenant l'endocardite varient largement dans la littérature. La plupart des spécialistes recommandent une antibiothérapie préventive chez les patients avec valvulopathie prédisposant à l'endocardite (surtout porteurs de prothèses valvulaires), ou si le risque de bactériémie est élevé après l'exécution de la démarche endoscopique. Tous les patients devraient traités comme s'ils pouvaient propager le virus d'hépatite $B$ ou d'immunodéficience humaine. Des précautions universelles devraient être prises dans les services d'endoscopie, et inclure le port de la blouse et des lunettes protectrices durant l'exécution de tous les procédés. L'étape la plus importante de la décontamination des endoscopes est la désinfection totale à froid de tous les instruments. Actif à la fois sur les virus de l'hépatite B et du SIDA, le glutaraldéhyde ( $2 \%$ ) est recommandé comme désinfectant de premier choix.

Division of Gastroenterology, The Wellesley Hospital; and the University of Toronto, Toronto, Ontario

Correspondence and reprints: Dr Gabor Kandel, The Wellesley Hospital, 160 Wellesley Street East, Toronto, Ontario M4Y $1 \mathrm{J3}$
T HE RISK OF BACTEREMIA AND endocarditis following gastrointestinal endoscopic procedures has been difficult to quantify. Consequently, a uniform consensus has not been reached on the need for prophylaxis in this setting.

The rationale for endocarditis prophylaxis is prevention of bacterial multiplication and adherence to the mucosal surfaces of heart valves following the bacteremia that occasionally occurs during endoscopy. No controlled trials addressing the efficacy of such prophylaxis exist; ethical considerations and the large number of subjects necessary to achieve statistical significance preclude such a study. Reports of endocarditis following gastrointestinal endoscopic procedures are uncommon, and the risks following newer interventional techniques such as laser and heater probe application are essentially unknown. Similarly, very little information is available regarding the need for prophylaxis in patients with ascites (ie, to prevent spontaneous bacterial peritonitis) or with prosthetic devices other than cardiac valves (eg, artificial vascular shunts or joints).

Recommendations are therefore based upon indirect information. The frequency of bacteremia after endoscopy has been shown to be related to the procedure being performed. In a review of 40 prospective studies, bacteremia occurred in less than $6 \%$ of patients after routine esophagogastroduodenoscopy, colonoscopy with or without biopsy or polypectomy, flexible or rigid sigmoidoscopy and diagnostic 
TABLE 1

\section{Cardiac conditions requiring antibiotic prophylaxis}

\begin{tabular}{lcccc}
\hline Condition & 1 & 2 & 3 & 4 \\
\hline Prosthetic cardiac valve & + & + & + & + \\
Most congenital defects & + & + & No & Opt \\
Surgical systemic-pulmonary shunts & + & ND & No & + \\
Rheumatic fever or other acquired defects & + & + & No & + \\
Idiopathic hypertrophic subaortic stenosis & + & + & No & Opt \\
Mitral valve prolapse & + & + & No & Opt \\
\hline
\end{tabular}

1 American Heart Association (3). Canadian Paediatric Society (4); 2 The Medical Letter (5); 3 British Society for Antimicrobial Chemotherapy (2): 4 American Society for Gastrointestinal Endoscopy (9).

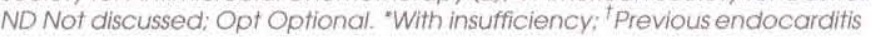

\section{TABLE 2}

\section{Summary of endocarditis antibiotic prophylaxis regimens}

\begin{tabular}{|c|c|c|c|}
\hline & Standard & Penicillin allergic & Oral regimen \\
\hline 1 & $\begin{array}{l}\text { Ampicillin } 2 \mathrm{~g} \mathrm{im} / \mathrm{iv} \text { plus } \\
\text { gentamicin } 1.5 \mathrm{mg} / \mathrm{kg} \\
\text { im/iv } 30 \mathrm{mins} \text { before and } \\
\text { optional } 8 \mathrm{~h} \text { follow-up }\end{array}$ & $\begin{array}{l}\text { Vancomycin } 1 \mathrm{~g} \text { iv for } 1 \mathrm{~h} \\
\text { plus gentamicin } 1.5 \mathrm{mg} / \mathrm{kg} \\
1 \mathrm{~h} \text { before and optional } \\
8 \text { to } 12 \mathrm{~h} \text { follow-up }\end{array}$ & $\begin{array}{l}\text { Amoxicillin } 3 \mathrm{~g} \text { po } 1 \mathrm{~h} \\
\text { before and } 1.5 \mathrm{~g} \mathrm{po} \\
6 \mathrm{~h} \text { after procedure } \\
\text { (for low risk situations) }\end{array}$ \\
\hline 2 & $\begin{array}{l}\text { Same as above but } 8 \mathrm{~h} \\
\text { dose suggested }\end{array}$ & Same as above & Same as above \\
\hline 3 & $\begin{array}{l}\text { Amoxicillin } 1 \mathrm{~g} \text { im plus } \\
\text { gentamicin } 120 \mathrm{mg} \text { im } \\
\text { and amoxicillin } 0.5 \mathrm{~g} \text { po } \\
6 \mathrm{~h} \text { after }\end{array}$ & $\begin{array}{l}\text { Vancomycin } 1 \mathrm{~g} \text { iv for } 1 \mathrm{~h} \\
\text { followed by gentamicin } \\
120 \mathrm{mg} \text { iv. Regimen also } \\
\text { for patients receiving } \\
\text { penicillin more than once } \\
\text { in previous month }\end{array}$ & None \\
\hline
\end{tabular}

1 American Heart Association (3), Canadian Paediatric Society (4); 2 The Medical Letter (5); 3 British Society for Antimicrobial Chemotherapy (2), im Intramuscular; iv Intravenous; po By mouth

endoscopic retrograde cholangiopancreatography (ERCP) (1). In contrast, esophageal dilation and variceal sclerotherapy were associated with mean bacteremia frequencies of 45 and $31 \%$, respectively. Nonhemolytic Streptococcus, Propionibacterium, and Neisseria species were the most commonly isolated organisms following esophagogastroduodenoscopy; enterococci, Escherichia coli and klebsiella were found after sigmoidoscopy; and Staphylococcus aureus and streptococci were most often isolated following esophageal manipulation.

Such studies form the basis of recommendations for endocarditis prophylaxis. In upper gastrointestinal procedures, the target organisms are alpha-hemolytic streptococci, primarily Streptococcus viridans, while in lower (colonic) procedures the major concern is enterococci. The chosen antibiotic must at the very least provide effective coverage against these organisms.

Most authorities agree that antibiotic prophylaxis is required for all patients with a prior history of bacterial endocarditis. Virtually all experts including the 'not antibiotic inclined' Endocarditis Working Party of the British Society for Antimicrobial Chemotherapy, recommend prophylaxis for patients with prosthetic heart valves as well (2). North American groups such as the American Heart Association (3), the Canadian Paediatric Society (4) and The Medical Letter (5) suggest antibiotic prophylaxis for patients with most congenital cardiac malformations (except atrial septal defect), rheumatic and other acquired valvular diseases, and surgically constructed systemic-pulmonary shunts, in addition to prosthetic valves (Table 1).

These authorities also consider the risks presented by various procedures. The American Heart Association (3) and the Canadian Paediatric Society (4) recommend endocarditis prophylaxis for esophageal sclerotherapy or dilation and colonoscopy and, if a biopsy is taken, for upper gastrointestinal endoscopy and sigmoidoscopy. While
The Medical Letter (5), the British Society for Antimicrobial Chemotherapy (2) and the American Society for Gastrointestinal Endoscopy (6) do not discuss specific procedures, The Medical Letter refers to another publication for risk of bacteremia (7) and the American Society for Gastrointestinal Endoscopy encourages the individual physician to make a decision based upon existing data and clinical information (6).

Periodic revisions are made by expert committees based upon emerging data. As noted in the revised American Heart Association recommendations, the trend is towards decreasing use of parenteral agents, and simplification of the prophylaxis regimen, enabling im. proved compliance among prac. titioners (8).

For example, the value of the post procedural antibiotic dose has been reassessed. Specific recommended regimens are provided in Table 2 .

A logical two-dimensional analysis of the risk of developing endocarditis in patients undergoing various gastrointestinal procedures has been proposed by Durack (9). The risk posed by the cardiac lesion is combined with the risk associated with the given procedure to create a matrix. Antibiotic prophylaxis is listed as recommended, optional or unnecessary on the basis of available information concerning each pair of parameters. Thus rationalizing the approach to endocarditis prophylaxis should be of benefit to the clinician. However, the matrix is limited by the availability of data concerning risk and the lack of studies on which antibiotic regimen is optimal in each situation.

As previously indicated, it is fortunate that bacterial endocarditis rarely results from gastrointestinal endoscopy. However, the potential severity and sequelae of this condition encourage the use of preventive measures. Diligent monitoring of endocarditis cases and antibiotic complications, assessment of bacteremia frequency associated with new endoscopic procedures, and im. proved knowledge of the pathogenesis of endocarditis are all required for im. provements in prophylaxis recommen. dations. Periodic review of available 
data and analysis of such within a rational framework will continue to be necessary to provide useful guidelines to clinicians.

\section{CLEANING AND DISINFECTION OF EQUIPMENT}

Infectious agents contaminating endoscopes most commonly originate from patients, although rare cases of contamination with opportunistic pathogens during storage have also been reported. Human immunodeficiency virus (HIV) and hepatitis B are the most serious threats to both patients and medical personnel. Endoscopic transmission has been responsible for only one well documented (and one poorly documented) case of hepatitis B; there have been no reports of acquired immune deficiency syndrome (AIDS) contracted in this manner.

Virtually all authorities now agree that universal blood and body precautions should be adopted. In other words, all patients should be presumed to have the ability to spread AIDS and other pathogens. This is necessary because accurate pre-endoscopic identification of such patients is impossible. The two tiered system of disinfection used in the past is not acceptable in the AIDS era.

Detailed instructions for the cleaning and disinfection of endoscopic equipment are available in numerous documents. The most recent of these is the recommendations of a working party of the British Society of Gastroenterology (10), which should be read in its entirety by any personnel responsible for the safety of an endoscopy unit. All recommendations emphasize that the most important aspect of cleaning is manual scrubbing of the endoscope and its channels with detergent, since without this admittedly laborious task, blood, mucus and organic material will prevent adequate penetration of even the most powerful disinfectant $(11,12)$. This scrubbing should then be followed by a 10 to 20 min soaking of the endoscope in $2 \%$ activated glutaraldehyde, which has been shown to be sufficient to inactivate virtually all vegetative bacteria and viruses (including HIV and hepatitis B virus) (10). This routine will not inactivate spores, with the exception of Clostridium difficile, but sporulating bacteria have never been a problem in endoscopy units. Mycobacterium contamination requires special procedures ( 1 h $2 \%$ glutaraldehyde soak) (13). Agents other than $2 \%$ alkaline glutaraldehyde cannot be recommended as first-line disinfection agents.

Autoclaving is another option but is impractical because $24 \mathrm{~h}$ is usually required before re-use, and repeated autoclaving damages endoscopes. It is important to appreciate that designated endoscopes are not generally recommended for HIV-infected (or hepatitis B) patients.

Ideally, endoscopes are dismantled between each case, adherent debris is brushed away, and the entire endoscope, including all lumens, is cleaned and flushed with fresh detergent. This is followed by a $10 \mathrm{~min}$ soak in $2 \%$ activated glutaraldehyde between cases, and 20 mins before and after starting the patient list. A similar approach is necessary for all auxiliary equipment such as biopsy forceps, brushes and papillotomes.

Problems with this approach include a need for two to three endoscopes per endoscopy room for efficient patient care, and the provision of exhaust extraction facilities (eg, hoods) to protect staff from aldehyde sensitization. This price is necessary, however, to prevent endoscopic transmission of a virulent pathogen.

Despite the infectivity of the hepatitis B virus, the risk of transmission by endoscopy appears to be minimal. O'Connor and Axon (14) reviewed nine prospective studies addressing the problem of hepatitis B transmission by endoscopy, and found that of 230 patients inadvertently examined with an endoscope that had been previously used to examine hepatitis B surface antigen ( $\mathrm{HBs} \mathrm{Ag}$ ) positive patients, only one patient became HBsAg positive (14). Even this patient did not develop any manifestations of liver disease. In the best documented example of hepatitis B transmission, the index patient had acute hepatitis $\mathrm{B}$ (suggesting high con- centrations of the virus in the blood) leading to massive variceal hemorrhage (suggesting heavy contamination of the endoscope), and the endoscope air/ water channel had not been flushed with a disinfectant (at that time the manufacturers did not recommend this procedure) (15).

The HIV virus is far less infective than hepatitis B virus. In fact, the risk of developing HIV infection even from needle stick exposure is less than $1 \%$. Moreover, routine soaking with $2 \%$ glutaraldehyde has been shown to inactivate HIV $(16,17)$. On the other hand, HIV has been isolated from virtually all body fluids, even though epidemiological studies to date have only implicated blood, semen, vaginal secretions and possibly breast milk in transmission of AIDS. In 1987 the Centers for Disease Control in the United States reported that three health care workers seroconverted to HIV infection after receiving splashes of infected blood on the skin and (in one case) the oral mucous membrane (18). Two of these personnel were not wearing gloves at the time of the accident. This emphasizes the importance of all endoscopic personnel wearing gloves, masks and eye protection. With such precautions, the risk of transmission of HIV or any pathogen is so minimal that protection of medical staff should not be a deterrent to offering endoscopy, as required, to all patients.

Patients known to be immunosuppressed, eg, symptomatic HIV cases, require special precautions to ensure that opportunistic organisms are not transmitted either from or to them. Accordingly, 1 h of glutaraldehyde disinfection of endoscopic equipment is required before and after endoscopy of such patients to ensure inactivation of mycobacteria and cryptosporidia (19).

\section{REFERENCE}

1. Botoman VA, Surawicz CM. Bacteremia with gastrointestinal endoscopic procedures. Gastrointest Endosc 1986;32:342-6.

2. Endocarditis Working Party of the British Society for Antimicrobial Chemotherapy. Antibiotic prophylaxis of infective endocarditis. Lancet 1990;i:88-9. 
3. Prevention of bacterial endocarditis: $A$ statement for health professionals by the Committee on Rheumatic Fever and Infective Endocarditis of the Council on Cardiovascular Disease in the Young. Circulation 1984;70:1123A$7 \mathrm{~A}$.

4. Canadian Pediatric Society, Infectious Disease and Immunization Committee. Prevention of bacterial endocarditis. Can Med Assoc J 1986;134:28-9.

5. Anon. Prevention of bacterial endocarditis. Med Lett 1984;26:3-4.

6. American Society for Gastrointestinal Endoscopy. Infection control during gastrointestinal endoscopy; guidelines for clinical application. Gastrointest Endosc 1986;34:37s-40s.

7. Everett ED, Hirschman JV. Transient bacteremia and endocarditis prophylaxis. Medicine 1977;56:61.

8. Kaye D. Prophylaxis for infective endocarditis: An update. Ann Intern Med 1986;104:419-23.
9. Durack DT. Current issues in prevention of infective endocarditis. Am J Med 1985;78:149-56.

10. Working Party of the British Society of Gastroenterology. Cleaning and disinfection of equipment for gastrointestinal flexible endoscopy: Interim recommendations of a Working Party of the British Society of Gastroenterology. Gut 1988;29:1134-51.

11. Gerding D, Peterson L, Vennes ]. Cleaning and disinfection of fiberoptic endoscopes: Evaluation of glutaraldehyde exposure time and forced air drying. Gastroenterology 1982;83:613-8.

12. Ayliffe GAJ, Babb JR, Bradley CR. Disinfection of endoscopes. J Hosp Infect 1986; 7:295-309.

13. Collins FM, Montalbine V. Mycobacterial activity of glutaraldehyde solutions. J Clin Microbiol 1976;4:408.

14. O'Connor HJ, Axon ATR. Gastrointestinal endoscopy: Infection and disinfection. Gut 1983;24:1067-77.
15. Birnie GG, Quigley EM, Clements GB, Follet EAC, Watkinson G. Endoscopic transmission of hepatitis B virus. Gut 1983;24:171-4.

16. Martin LA, McDougal JS, Loskoski SC. Disinfection and inactivation of the human T lymphotropic virus type III/ lymphadenopathy-associated virus. J Infect Dis 1985;2:400-3.

17. Spire B, Barre-Sinoussi F, Montagnier $\mathrm{L}$, Chermann JC. Inactivation of lymphadenopathy associated virus by chemical disinfectants. Lancet 1984;i:899-901.

18. Centers for Disease Control. Update: Human immunodeficiency virus infections in health care workers exposed to blood of infected patients. MMWR 1987;36:285-9.

19. Axon ATR, Cotton PB. Endoscopy and infection. Report and recommendations of the Endoscopy Committee of the British Society of Gastroenterology. Gut 1983;24:1064-6. 


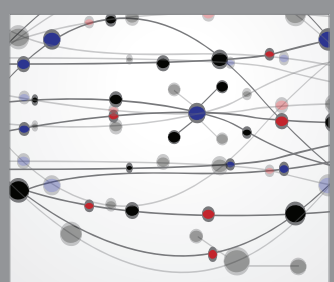

The Scientific World Journal
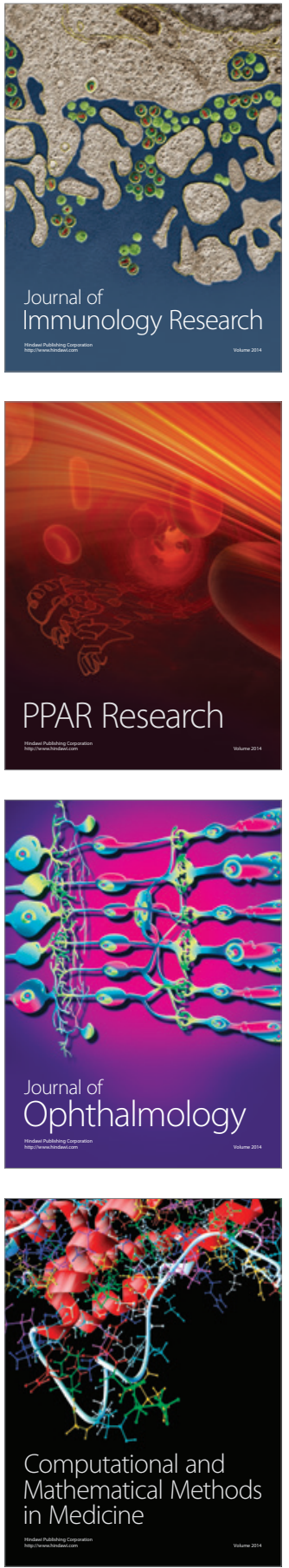

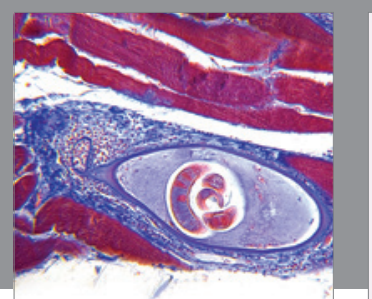

Gastroenterology Research and Practice

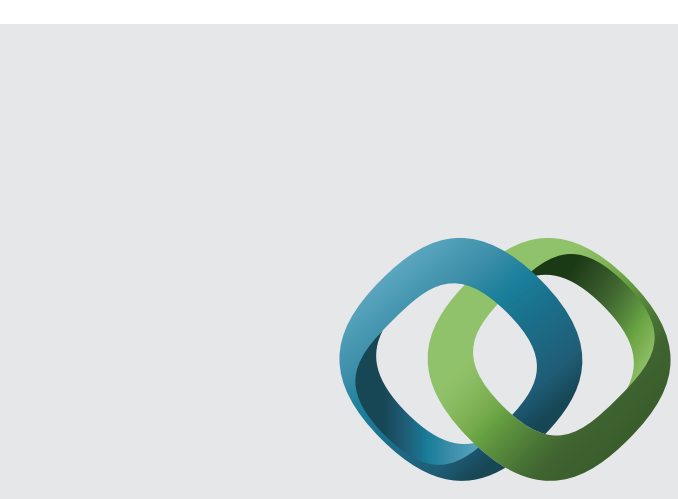

\section{Hindawi}

Submit your manuscripts at

http://www.hindawi.com
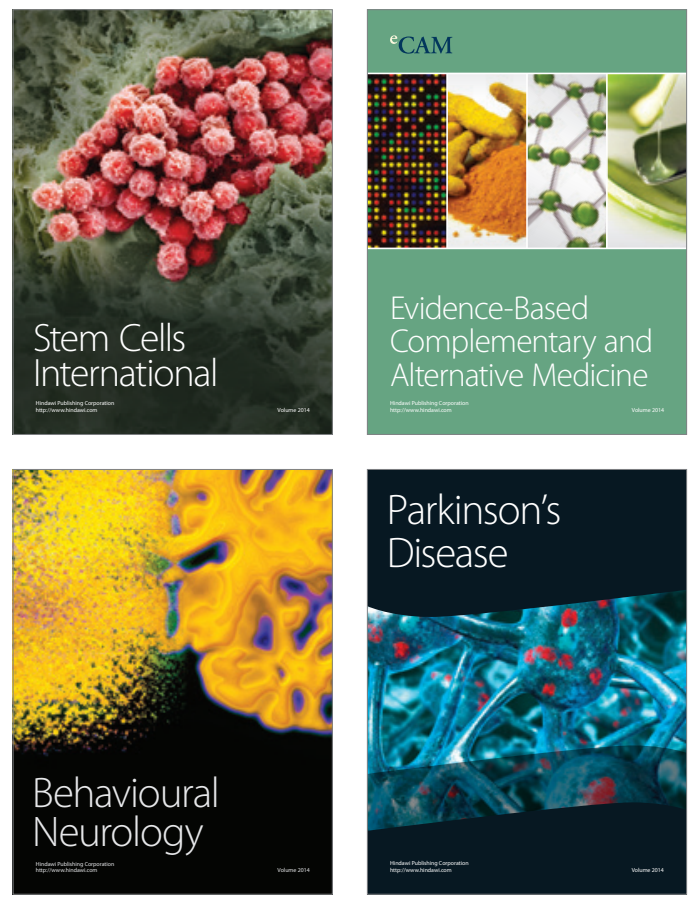
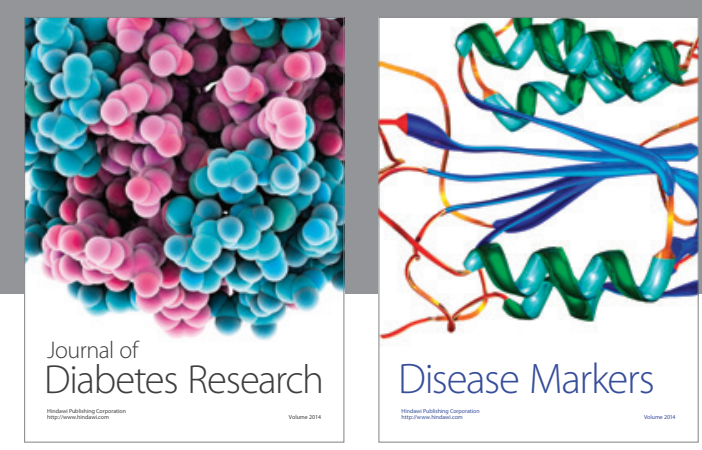

Disease Markers
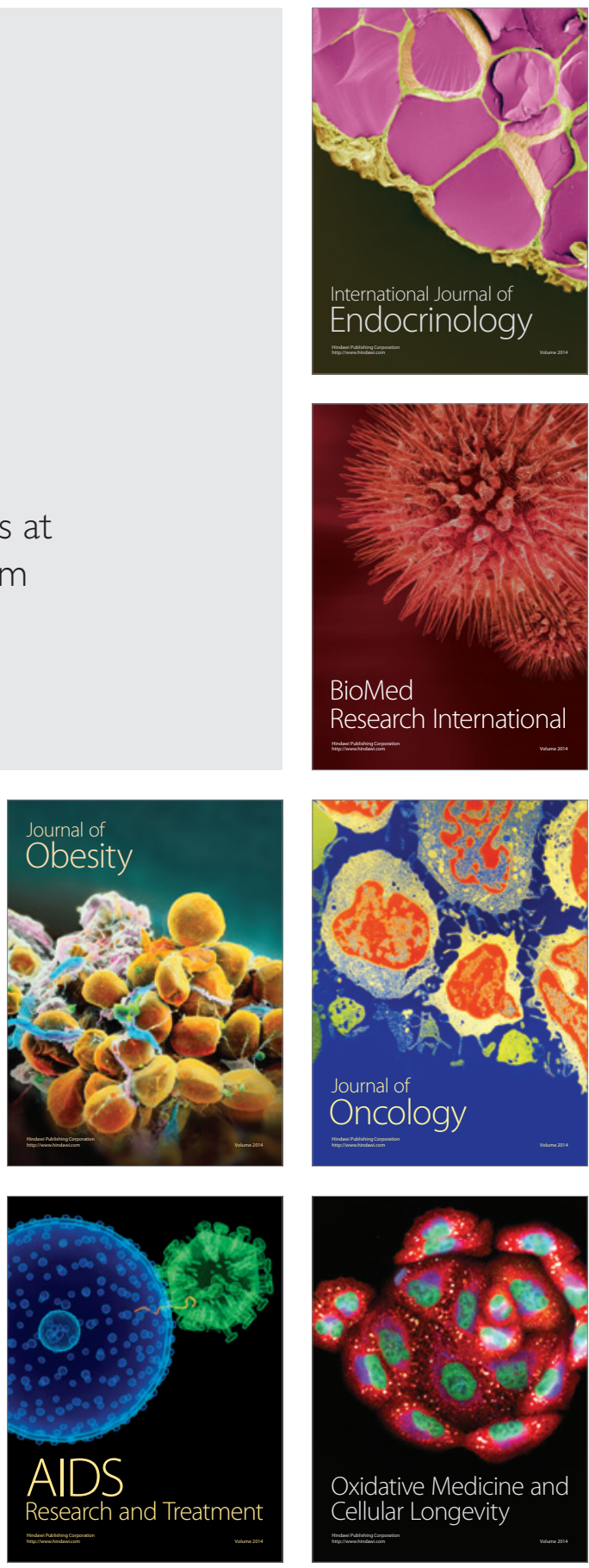